Zeszyty Naukowe Szkoły Głównej Gospodarstwa Wiejskiego w Warszawie

Problemy Rolnictwa Światowego tom 18 (XXXIII), zeszyt 4, 2018: 270-283

DOI: 10.22630/PRS.2018.18.4.117

Włodzimierz Kołodziejczak ${ }^{1}$

Uniwersytet Przyrodniczy w Poznaniu

\title{
Zatrudnienie i wartość dodana brutto w sektorach gospodarki państw Unii Europejskiej w latach 2002 i $2016^{2}$
}

\section{Employment and Gross Value Added in the Sectors of the European Union Economy in 2002 and 2016}

\begin{abstract}
Synopsis. Celem artykułu jest rozpoznanie poziomu zatrudnienia i wytwarzanej wartości dodanej brutto w rolnictwie na tle pozostałych sektorów gospodarki w państwach Unii Europejskiej. W badaniu zastosowano analizę porównawczą i dedukcję. Wykorzystano dane EUROSTAT z lat 2002 i 2016. "Nadwyżka" zatrudnienia $\mathrm{w}$ rolnictwie występująca $\mathrm{w}$ państwach postsocjalistycznych $\mathrm{w}$ stosunku do średniej UE odpowiada w nich, w przybliżeniu, „niedoborowi” zatrudnienia w usługach. Proces zmian sektorowej struktury zatrudnienia będzie prawdopodobnie warunkowany przez tempo wzrostu zapotrzebowania na usługi, dostosowanie strukturalne dotyczące dopasowania cech ludności rolniczej do zapotrzebowania na siłe roboczą w sektorze usług oraz tempo przekształceń strukturalnych na wsi.
\end{abstract}

Słowa kluczowe: sektorowa struktura zatrudnienia, wartość dodana brutto, zatrudnienie w rolnictwie, Unia Europejska

\begin{abstract}
The aim of the paper is to recognize the level of employment and gross value added in the agriculture against the other sectors of the economy in the European Union. Comparative analysis and method of deduction were used in the study. The research was based on the EUROSTAT data from the years of both 2002 and 2016. The "surplus" of employment in the agriculture in the post-socialist countries in relation to the EU average approximately corresponds to the "shortage" of employment in services. The process of changes in the sectoral structure of employment will probably be determined by the growth rate of demand for services, structural adjustment referring to matching the characteristics of the agricultural population to the demand for labour force in the services sector and the pace of structural transformations in rural areas.
\end{abstract}

Key words: sectoral structure of employment, gross value added, employment in agriculture, European Union

JEL Classification: J21, O57, P52

\section{Wprowadzenie}

Według teorii trzech sektorów, w ramach gospodarki narodowej każdego kraju można wyróżnić rolnictwo, przemysł i usługi (Fisher, 1933, 1939; Flejterski, Klóska, Majchrzak, 2012). Przyjmuje się, że udział każdego z tych sektorów w tworzeniu PKB oraz w strukturze zatrudnienia świadczy o poziomie rozwoju gospodarczego kraju oraz ma silny

\footnotetext{
${ }^{1}$ dr inż., Uniwersytet Przyrodniczy w Poznaniu, Katedra Finansów i Rachunkowości, ul. Wojska Polskiego 28, 60-637 Poznań, e-mail: kolodziejczak@up.poznan.pl; https://orcid.org/0000-0001-7315-6717

${ }^{2}$ Badanie i publikację sfinansowano ze środków Narodowego Centrum Nauki w ramach projektu badawczego MINIATURA Nr NCN DEC-2017/01/X/HS4/00565: „Determinanty aktywności ekonomicznej ludności wiejskiej w Polsce. Możliwości redukcji bezrobocia ukrytego w rolnictwie”.
} 
związek z jego nowoczesnością i konkurencyjnością, a w ślad za tym określa w znacznym stopniu bogactwo i poziom życia ludności. Wraz z rozwojem gospodarczym i postępem cywilizacyjnym najpierw zmniejsza się rola rolnictwa na rzecz przemysłu, a później rolnictwa i przemysłu na rzecz usług (M. Kołodziejczak, 2016). Ma to uzasadnienie między innymi w wyższej produktywności pracy i kapitału w przemyśle i usługach, ale także jest konsekwencją zmian postaw społecznych (Fisher 1945, Kwiatkowski 1980) między innymi ewolucją od homo oeconomicus do homo sustinens (Kraciuk, 2015; Kiełczewski 2016). W przypadku ziemi, produktywność wzrasta wolniej niż produktywność pracy i kapitału poza rolnictwem. Równocześnie, wzrost produktywności ziemi, nie musi oznaczać wyższej wartości dodanej generowanej przez rolnictwo, a wobec ograniczonych możliwości wzrostu produktywności ziemi i kapitału, bez redukcji zatrudnienia nie można osiagnąć również wzrostu produktywności pracy $\mathrm{w}$ tym sektorze. Zmiany sektorowej struktury zatrudnienia $\mathrm{w}$ kierunku zmniejszania udziału rolnictwa określają więc $\mathrm{w}$ przybliżeniu liczbę osób, między które musi zostać podzielona, względnie stała, wytworzona przez ten sektor wartość dodana. W tym układzie odniesienia, ewolucja struktury zatrudnienia w kierunku zwiększania udziału bardziej produktywnych sektorów (usług i częściowo przemysłu) warunkuje przebieg procesów konwergencji dochodów osób pracujących w rolnictwie i poza nim. Wyższa produktywność przemysłu i usług oznacza także, że zaangażowane w nich praca i kapitał wytwarzają większą wartość dodaną niż rolnictwo, więc zmniejszanie zatrudnienia w rolnictwie na rzecz tych sektorów stymuluje procesy wzrostu i rozwoju w skali całej gospodarki. Te prawidłowości znajdują potwierdzenie w zmianach poziomu dochodów rolniczych $w$ państwach Unii Europejskiej. Badania prowadzone przez Zawalińską i in. (2015) wykazały, że w latach 2000-2013 dochody rolnicze rosły $\mathrm{w}$ ujęciu absolutnym wraz $\mathrm{z}$ rozwojem gospodarczym, ale malały $\mathrm{w}$ strukturze PKB, przy czym wzrost dochodów rolniczych w ujęciu absolutnym wynikał częściowo $\mathrm{z}$ uwzględnienia $\mathrm{w}$ nich dotacji $\mathrm{w}$ ramach WPR. Oznacza to, że pomimo pozytywnych zmian $\mathrm{w}$ produktywności rolnictwa, efektywność czynników produkcji wzrastała szybciej w przemyśle i usługach (Por. Wąsowicz, 2013)³.

Nadmierne zatrudnienie utrudnia osiaggnięcie wzrostu wydajności pracy w rolnictwie ${ }^{4}$, zwłaszcza wobec ograniczeń przyrodniczych, rynkowych i instytucjonalnych, stanowi przeszkodę także dla osiąnnięcia celów ekonomicznego zrównoważenia rolnictwa ${ }^{5}$. Przy

\footnotetext{
3 Problem ten występował również wcześniej, jednak miał różne przyczyny w państwach socjalistycznych i zachodnich. Czyżewski (1989) podaje, że przyczyną tworzenia się dysparytetu w gospodarce socjalistycznej było dążenie do zapewnienia niskich kosztów utrzymania robotników, konieczne ze względu na dążenie do industrializacji gospodarki w warunkach niskiej efektywności ekonomicznej pracy w przemyśle socjalistycznym. Ponieważ nie można było zapewnić odpowiednio wysokich wynagrodzeń robotników, ustalano niskie i administracyjnie regulowane ceny żywności. Można przyjąć, że zjawisko to dotyczyło wszystkich państw byłego RWPG. Odmiennie, w państwach zachodnich powstawanie dysparytetu wynikało (podobnie jak współcześnie) z niższej efektywności czynników produkcji w rolnictwie w porównaniu z przemysłem i usługami.

${ }^{4}$ Doward (2013) wskazuje na częste pomijanie tego zagadnienia w dyskusji o polityce rolnej.

${ }^{5}$ Koncepcja zrównoważonego rozwoju w odniesieniu do rolnictwa obejmuje trzy wymiary: ekonomiczny, społeczny i środowiskowy (Czyżewski, 2012; M. Kołodziejczak, 2018). Doświadczenia krajów rozwijających się wskazują, że pominięcie któregokolwiek z aspektów zrównoważenia prowadzi w dłuższej perspektywie do powstawania wysokich kosztów we wszystkich trzech wymienionych wymiarach i do niewydolności rolnictwa jako sektora odpowiedzialnego za produkcję żywności (por. Matuszczak, 2013). O zrównoważeniu można mówić jedynie, kiedy produkcja rolnicza wykorzystuje zasoby kapitału, pracy i środowiska w sposób optymalny z punktu widzenia teraźniejszości i przyszłości. Jednym z wymiarów zrównoważenia rozwoju rolnictwa jest wielkość zatrudnienia w tym sektorze. Nadmierne zatrudnienie uniemożliwia realizację celów ekonomicznych koncepcji
} 
ograniczonej możliwości zwiększenia produkcji rolniczej i jej opłacalności, ten parametr decyduje w znacznej mierze o poziomie dochodów rolników, ponieważ określa liczbę osób, między które będzie dzielony dochód uzyskiwany z gospodarstwa. To przekłada się na poziom i jakość życia członków gospodarstw rolniczych i - pośrednio - na poziom i jakość życia innych mieszkańców wsi i mieszkańców miast. Zbyt duże zasoby pracy zawiązane $\mathrm{z}$ rolnictwem zniechęcają do podejmowania starań w kierunku unowocześniania produkcji, ponieważ inwestycje lub korzystanie z usług są często niekonkurencyjne ekonomicznie wobec użycia taniego (nisko opłacanego) zasobu pracy, zwłaszcza, jeżeli jest to praca własna rolnika i pomagających członków rodziny, a zwiększenie jej nakładu nie powoduje zmiany realnie ponoszonego kosztu. Liczba osób w gospodarstwie domowym rolnika jest bowiem względnie stała, a sam fakt realnego udziału w procesie produkcyjnym części lub wszystkich osób nie zmienia łącznego zasobu dochodu z gospodarstwa do podziału między domowników, ani liczby osób, między które trzeba ten dochód podzielić ${ }^{6}$. Ponadto, jak można przypuszczać, opisywane przez Rembisza (2016) przeszacowanie wynagrodzenia pracy $\mathrm{w}$ rolnictwie $\mathrm{w}$ stosunku do jego wydajności spowalnia procesy uwalniania $\mathrm{z}$ rolnictwa nadwyżek zatrudnienia i długookresowo utrwala strukturalne podstawy dysparytetu dochodowego rolników względem pracujących w sektorach pozarolniczych (chociaż krótkookresowo może ten dysparytet zmniejszać).

Redukcja dysparytetu dochodowego rolników jest niezbędnym elementem dążenia do rolnictwa zrównoważonego w sensie Pareto (Czyżewski, 2012), ponieważ stanowi element ekonomicznego wymiaru tego procesu, a pośrednio (na skutek oddziaływania wyższych dochodów na poziom i jakość życia na wsi), również kształtuje jego wymiar społeczny. Jednak trudno mówić o zrównoważeniu w sensie ekonomicznym, jeżeli nie zostanie zachowana zasada, że (przede wszystkim) produktywność czynników finansuje ich wynagrodzenie (por. Rembisz, 2016). Zatem, odnosząc się do rolnictwa, wydaje się słusznym poszukiwanie możliwości finansowania dochodów osób zatrudnionych w tym sektorze najpierw z jego produktywności, a dopiero później rozważanie transferów środków wypracowanych $\mathrm{w}$ innych sektorach. Wobec opisywanego w literaturze przedmiotu wyczerpywania się możliwości wzrostu nadwyżki generowanej przez rolnictwo, drogą do minimalizacji dysparytetu dochodowego rolników jest więc przede wszystkim zmniejszenie zatrudnienia $\mathrm{w}$ gospodarstwach rolnych (i, szerzej, w sektorze rolnym).

Warto więc podjać próbę nakreślenia obrazu poziomu zatrudnienia w poszczególnych sektorach gospodarki oraz generowanej przez nie wartości dodanej, która w pierwszej kolejności (tzn. zwłaszcza przed środkami transferowymi) powinna stanowić źródło wynagrodzenia pracy, szczególnie w specyficznym sektorze, jakim jest rolnictwo. Dlatego jako cel artykułu przyjęto rozpoznanie poziomu zatrudnienia i wytwarzanej wartości dodanej brutto $\mathrm{w}$ rolnictwie na tle pozostałych sektorów gospodarki w państwach Unii Europejskiej. Stanowi to kanwę do rozważań prowadzonych w kontekście możliwości redukcji dysparytetu dochodowego ludności rolniczej poprzez dalsze zmniejszanie zatrudnienia w tym sektorze na rzecz usług i przemysłu.

zrównoważenia oraz utrudnia dążenie do osiagania celów społecznych i zachowania zasobów środowiskowych w niepogorszonym stanie.

${ }^{6}$ Jest to oczywiście zachowawcza i długookresowo nieracjonalna strategia zarządzania gospodarstwem, a jej przyjęcie może wynikać z braku wiedzy, kwalifikacji, kapitału lub (częściej) z braku możliwości pozyskania zatrudnienia poza gospodarstwem. 


\section{Uwagi metodyczne}

Aby osiagnąć postawiony cel, zastosowano analizę porównawczą i dedukcję. Wykorzystano dane EUROSTAT dotyczące zatrudnienia i wartości dodanej brutto (WDB) generowanej przez rolnictwo, przemysł i usługi w państwach UE-25 oraz literaturę przedmiotu ( $\mathrm{z}$ uwagi na niewielkie znaczenie rolnictwa $\mathrm{w}$ gospodarce pominięto Cypr i Maltę). Analizę przeprowadzono na podstawie danych z lat 2002 i 2016. Na podstawie zestawienia i porównania informacji dotyczących udziału rolnictwa $w$ strukturze zatrudnienia oraz $\mathrm{w}$ wytwarzaniu WDB podjęto próbę wnioskowania na temat natury i przyczyn różnic występujących w tym zakresie pomiędzy poszczególnymi krajami UE oraz zmian zaobserwowanych pomiędzy badanymi latami. Przeanalizowano także wielkość WDB przypadającą na jednego zatrudnionego $\mathrm{w}$ rolnictwie $\mathrm{w}$ rolnictwie $\mathrm{w}$ relacji do WDB w przemyśle i usługach. Daje to pewien obraz dystansu, jaki dzieli ludność rolniczą od nierolniczej w zakresie efektywności pracy, która stanowi o możliwościach redukcji dysparytetu dochodowego dzielącego ludność rolniczą od osób pracujących w przemyśle i usługach. Podjęto także próbę przewidywania przebiegu procesów przekształceń struktury zatrudnienia w przyszłości, w zakresie dotyczącym rozkładu odpływu siły roboczej z rolnictwa do przemysłu i usług. Z oczywistych względów, nie sposób było uniknąć pewnych uproszczeń, jednak na zastosowanym, dość ogólnym poziomie analizy i wobec ograniczeń dotyczących objętości tekstu, dalsze uszczegółowienie nie było celowe.

\section{Wyniki badań i dyskusja}

$\mathrm{Na}$ rysunku 1 przedstawiono strukturę zatrudnienia w poszczególnych sektorach gospodarki w państwach Unii Europejskiej w 2002 i 2016 roku. Można zauważyć, że we wszystkich państwach poddanych badaniu udział rolnictwa w strukturze zatrudnienia uległ w badanym okresie zmniejszeniu, najwyraźniej wśród państw charakteryzujących się najwyższym udziałem zatrudnienia w rolnictwie w obydwu zaprezentowanych latach. Unowocześnianie rolnictwa i zwiększanie koncentracji gruntów skutkujące mniejszym realnym zapotrzebowaniem na pracę ludzką, finansowane w dużej części ze środków WPR i programów strukturalnych EU, dodatkowo stymulowały procesy uwalniania zasobów pracy z rolnictwa indywidualnego. Dofinansowanie ze środków WPR nie poprawiało jednak znacząco poziomu dochodów ludności rolniczej, a jednocześnie w określonych warunkach, mogło się przyczyniać do utrwalania niekorzystnej z punktu widzenia ekonomicznego struktury użytkowania ziemi i nadmiernego zatrudnienia w niewielkich gospodarstwach rodzinnych. Pomimo ogólnie korzystnego wpływu WPR, dopłaty nie związane z wielkością produkcji rolniczej mogą oddziaływać niekorzystnie zwłaszcza w części strukturalnej zjawiska nadmiernego zatrudnienia w rolnictwie. Z punktu widzenia osób związanych z gospodarstwami nieefektywnymi ekonomicznie, działają bowiem podobnie jak zasiłki dla bezrobotnych, zmniejszając motywację do poszukiwania pracy (W. Kołodziejczak 2016a). Równocześnie następowały więc dwa zjawiska: absorpcja uwalnianych $\mathrm{z}$ rolnictwa zasobów pracy przez sektory pozarolnicze oraz tworzenie technologicznych i organizacyjnych podstaw do uwydatnienia braku celowości utrzymywania nadmiernego zatrudnienia w gospodarstwach. 
2002

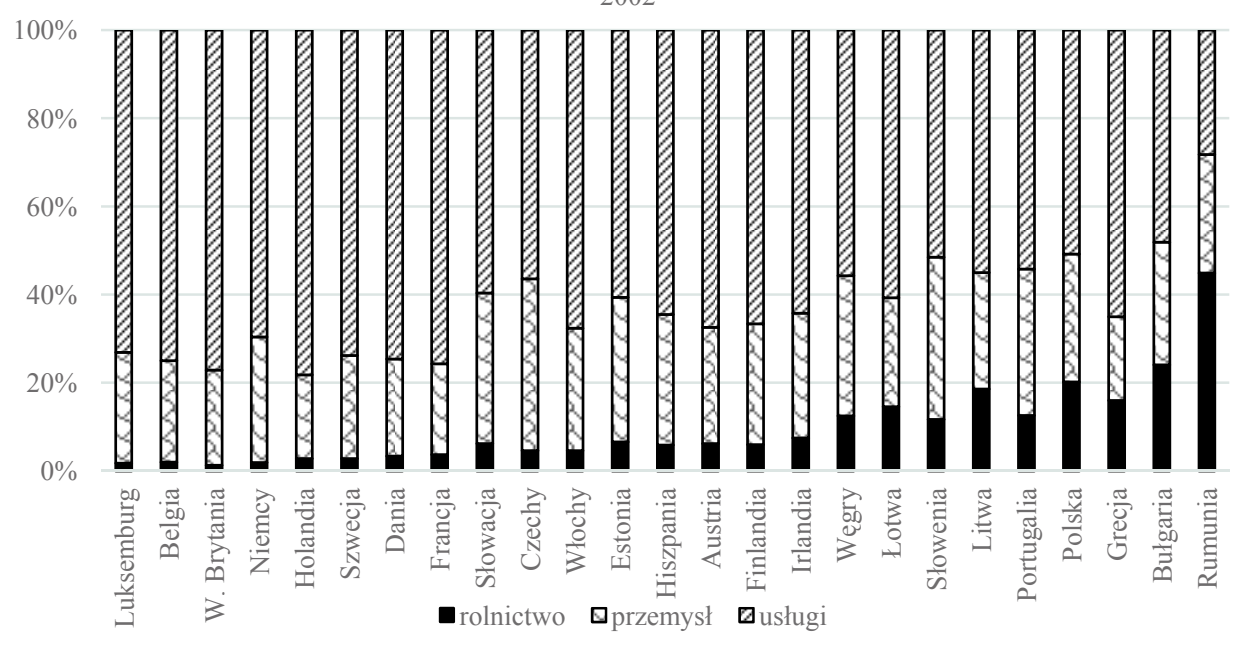

2016

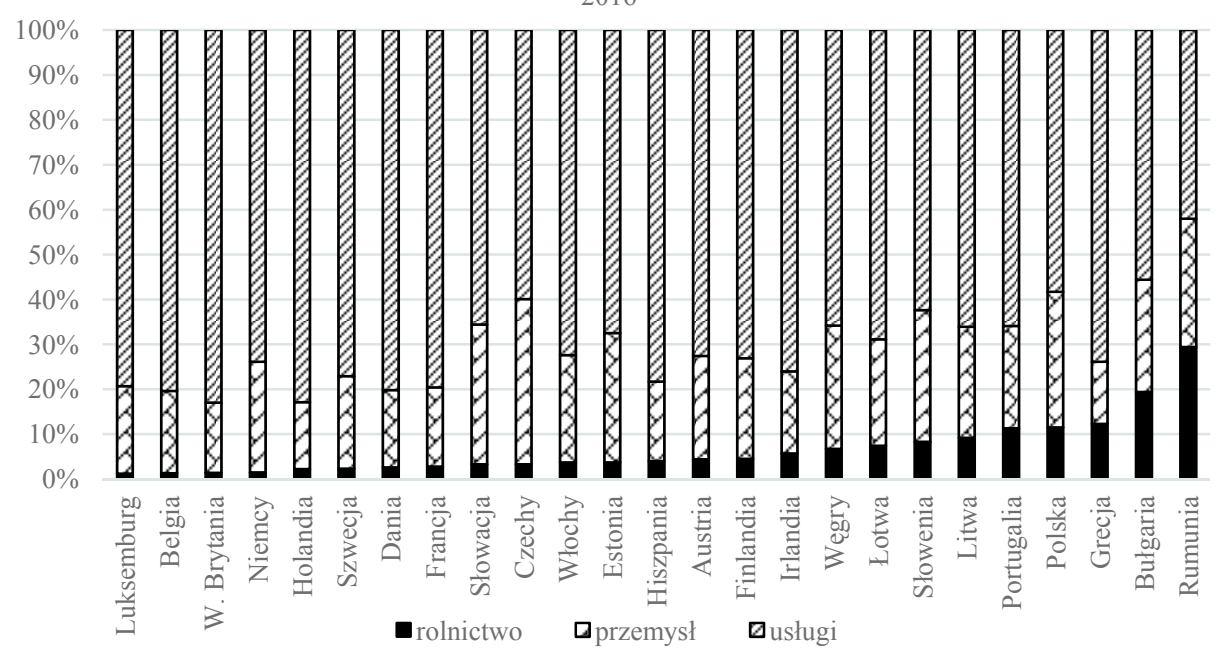

Rys. 1. Zatrudnienie w sektorach gospodarki państw UE w 2002 i 2016 roku (\%)

Fig. 1 Employment in the EU countries by sectors of the economy in 2002 and 2016 (\%)

Źródło: opracowanie na podstawie danych EUROSTAT (2018).

W badanych latach udział zatrudnienia w przemyśle nie zmieniał się tak wyraźnie jak w przypadku rolnictwa (zwłaszcza w państwach postsocjalistycznych), natomiast wzrastał udział sektora usług (rys. 1). Można więc przyjąć (pomijając wpływ czynników demograficznych), że absorpcja siły roboczej uwalnianej z rolnictwa dokonywała się przede wszystkim przez sektor usługowy. Spośród badanych państw, najwyższy udział zatrudnienia w rolnictwie w ogólnej liczbie pracujących w gospodarce narodowej w 2016 
roku odnotowano w Rumunii, Bułgarii, a następnie w Grecji, Polsce i Portugalii. Najmniejszy udział zatrudnionych $w$ rolnictwie występował w silnych gospodarczo państwach Europy Zachodniej: w Luksemburgu, Belgii, Wielkiej Brytanii, Niemczech i Szwecji. Wśród państw o niskim udziale rolnictwa w strukturze zatrudnienia znajdują się jednak także przedstawiciele części środkowej i wschodniej Europy: Słowacja, Czechy i Estonia. Już taka obserwacja pozwala domyślać się, że dla kształtowania sektorowej struktury zatrudnienia ma znaczenie przede wszystkim poziom rozwoju gospodarczego, ale także zaszłości historyczne. Wymienione państwa Europy Środkowo-Wschodniej posiadaja większy udział przemysłu w strukturze zatrudnienia niż państwa Europy Zachodniej. Jest to w znacznej części spowodowane dążeniem do wzrostu udziału przemysłu w gospodarkach socjalistycznych, a równocześnie sukcesem przeprowadzanej kolektywizacji i nacjonalizacji rolnictwa. Państwa postsocjalistyczne o wysokim udziale rolnictwa w sektorowej strukturze zatrudnienia: Rumunia, Bułgaria, Polska, Słowenia i Węgry posiadaja jednocześnie porównywalny między nimi udział zatrudnienia $\mathrm{w}$ przemyśle (wyższy niż państwa zachodnie), natomiast „nadwyżka” zatrudnienia w rolnictwie występująca w stosunku do średniej UE odpowiada w nich, w przybliżeniu, „niedoborowi” zatrudnienia $\mathrm{w}$ usługach. Zatem można spodziewać się, że podobnie jak w latach 20022016 (rys. 1), dalsze procesy zmian sektorowej struktury zatrudnienia będą przebiegały $\mathrm{z}$ „pominięciem” klasycznego wzorca teorii trzech sektorów, a uwalniania z rolnictwa ludność będzie absorbowana przez sektor usług. Proces ten będzie prawdopodobnie warunkowany przez tempo wzrostu zapotrzebowania na usługi, dostosowanie strukturalne dotyczace dopasowania cech ludności rolniczej do zapotrzebowania na siłe robocza w sektorze usług (kwalifikacje, mobilność, czynniki płacowe w powiązaniu z kosztami podjęcia pozarolniczego zatrudnienia) oraz tempo przekształceń strukturalnych na wsi (modernizację procesów produkcji i konsolidację własności oraz użytkowania ziemi rolniczej)

Jak wspomniano wcześniej, wśród wielu przyczyn określających kierunek przekształceń sektorowej struktury zatrudnienia, ważne miejsce zajmuje efektywność wykorzystania zaangażowanych czynników produkcji. O ile w przypadku przemysłu i usług postęp w tym zakresie jest dość szybki, to rolnictwo napotyka na istotne ograniczenia, wynikające z jego przyrodniczej natury, pełnionych funkcji społecznych i uwarunkowań instytucjonalnych (np. regulacji WPR). Procesy modernizacji, postęp biologiczny, technologiczny i organizacyjny prowadzą zwykle do zwiększenia wydajności produkcji, jednak tylko do pewnego poziomu, wyznaczanego przez produktywność ziemi, zwierząt oraz ograniczenia $\mathrm{W}$ zakresie dopuszczalnej powierzchni zasiewów poszczególnych roślin, wielkości stada, możliwości stosowania nawozów, pestycydów, herbicydów, organizmów modyfikowanych genetycznie, dopuszczalnego poziomu cen lub wprost - limity wielkości produkcji (np. obowiązujące przez wiele lat limity produkcji mleka). To sprawia, że dochody gospodarstw $\mathrm{z}$ produkcji rolniczej nie mogą rosnąć porównywalnie do dochodów przedsiębiorstw usługowych lub przemysłowych (oczywiście, jest to nieco uproszczony obraz). Zatem kluczową sprawą staje się zmniejszenie liczby osób, między które ta ograniczona wartość dodana i dochód będą dzielone.

Jeżeli pominąć środki transferowe, to dochód gospodarstwa rolnego jest uzależniony przede wszystkim od generowanej przez nie wartości dodanej. W bogatszych państwach zachodnich rolnictwo wytwarza tak niewielką czesść WDB w stosunku do przemysłu i usług, że staje się ona niemal niezauważalna na wykresie (rys. 2.). Porównanie struktury 
wytwarzanej przez poszczególne sektory wartości dodanej brutto (WDB) (rys. 2) i relacji WBD per capita w rolnictwie w stosunku do przemysłu i usług (rys. 3) wskazuje także, że wysokie zatrudnienie w rolnictwie nie wspólistnieje z wysokim poziomem WDB.

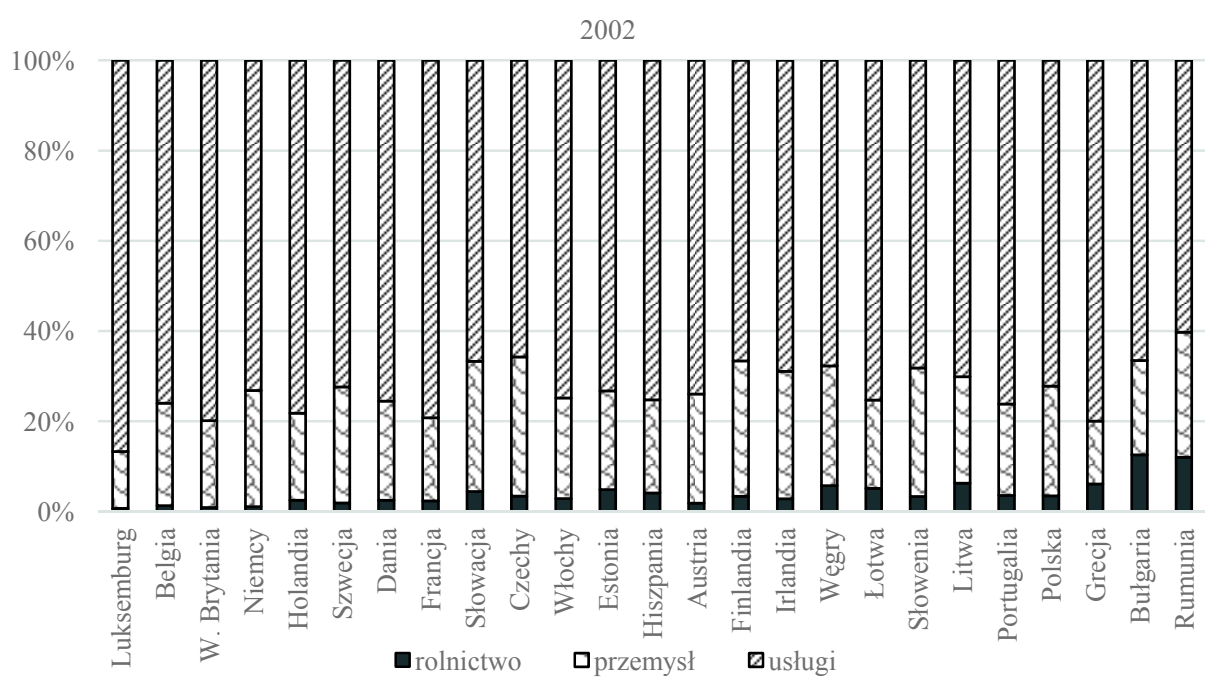

2016

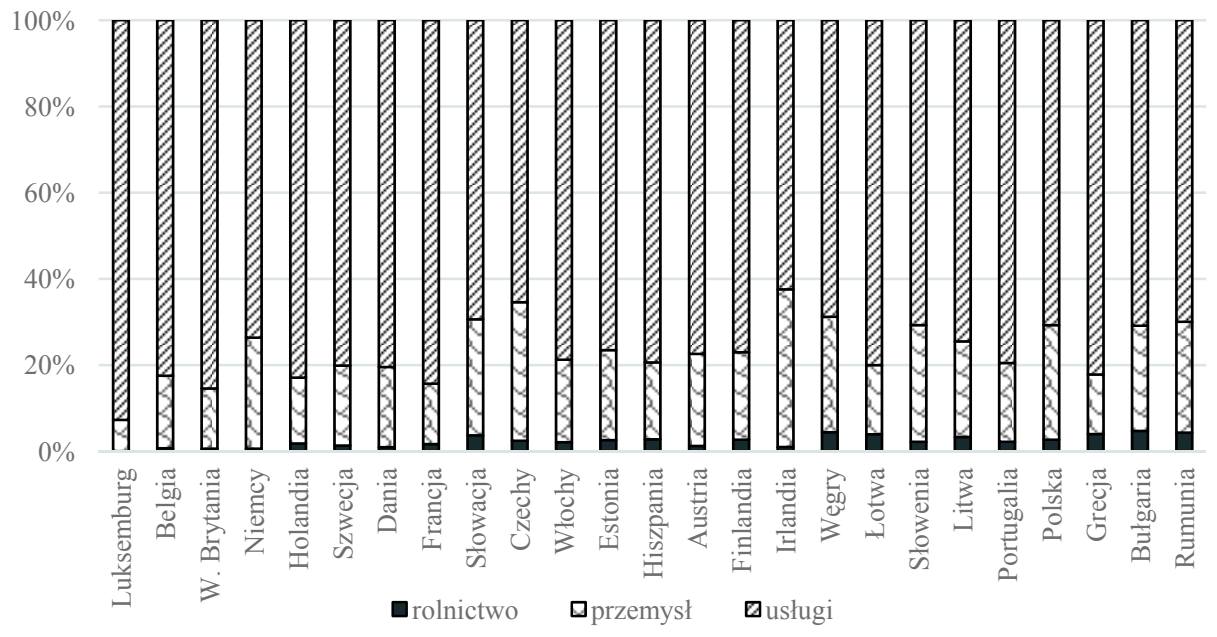

Rys. 2. Struktura WDB wytwarzanej w sektorach gospodarki krajów UE w 2002 i 2016 roku (\%)

Fig. 2. Structure of GVA in the EU countries by sectors of the economy in 2002 and 2016 (\%)

Źródło: opracowanie na podstawie danych EUROSTAT (2018).

Można zauważyć, że nawet ta niewielka część generowana przez rolnictwo zmalała w latach 2002-2016 (rys. 2). Redukcja jest najsilniej zauważalna w państwach, w których występowało najwyższe zatrudnienie w rolnictwie i w których to zatrudnienie w badanym 
okresie zmalało. Jednak nie należy wprost wiązać ze sobą tych dwóch zjawisk. Zmniejszenie udziału rolnictwa w strukturze wartości dodanej brutto wynikało bowiem nie tyle $\mathrm{z}$ redukcji zatrudnienia $\mathrm{w}$ tym sektorze, co ze wzrostu poziomu WDB w przemyśle i usługach, miało więc to samo podłoże co w krajach lepiej rozwiniętych gospodarczo. Pośrednio, pewne znaczenie mogło mieć zwiększenie zatrudnienia poza rolnictwem, jednak przede wszystkim przemiany sektorowej struktury wytwarzania WDB były kształtowane przez różne tempo wzrostu produktywności w poszczególnych sektorach. Warto także zauważyć, że o ile w przypadku produkcji przemysłowej relacje pomiędzy udziałem przemysłu w sektorowej strukturze zatrudnienia zaprezentowanej na rysunku 1 a wielkością WDB są zbliżone w poszczególnych krajach, to równocześnie wyraźnie widać, że „brakująca” część WDB w krajach o wysokim poziomie zatrudnienia w rolnictwie wytwarzana jest przez sektor usług. Państwa te charakteryzują się zwykle niższą WDB w skali całej gospodarki, można więc przypuszczać, że WDB niewytworzona przez „nadmiarowe” zatrudnienie w rolnictwie po prostu przepada. Z tego punktu widzenia, wielkość zatrudnienia w rolnictwie odpowiadająca utraconej WDB określa w przybliżeniu poziom nieefektywnej nadwyżki zatrudnienia w sektorze rolniczym, inaczej nazywanej bezrobociem ukrytym. Również uwzględnienie transferów przekazywanych w ramach WPR nie poprawia wyraźnie sytuacji dochodowej rolników i nie zawsze ich wpływ na sytuację ludności rolniczej można oceniać jednoznacznie jako pozytywny. Góral i Rembisz (2018), wskazują że wynagrodzenia w rolnictwie są zawyżone w stosunku do osiaganej wydajności pracy. Zwracają także uwagę na niekorzystny wpływ tego zjawiska na przebieg procesów realokacji siły roboczej $\mathrm{z}$ rolnictwa do sektorów o wyższej wydajności (przemysłu i usług). Z tego punktu widzenia, dofinansowanie nieefektywnych gospodarstw na zjawisko nadmiernego zatrudnienia oddziałuje podobnie, jak zbyt wysokie zasiłki na poziom bezrobocia jawnego, zniechęcając do aktywizacji i poszukiwania alternatywnych, zarobkowych źródeł dochodów (Kołodziejczak i Wysocki, 2015).

$\mathrm{Na}$ rysunku 3 przedstawiono WDB na jednego zatrudnionego w rolnictwie w relacji do WDB na jednego zatrudnionego w przemyśle i usługach w krajach UE w 2002 i 2016 roku. Można zauważyć, że relacja dochodu rolników do osób pracujących w przemyśle i usługach w badanych latach uległa zmianie na niekorzyść rolnictwa, jednak proces ten nie przebiegał jednakowo we wszystkich państwach. Pewien wpływ miało objęcie w 2004 roku nowych członków Unii Europejskiej systemem dopłat, jednak silniej oddziaływały zmiany poziomu dochodów w przemyśle i usługach, związane ze wzrostem gospodarczym i wspomnianym wcześniej, szybszym wzrostem produktywności czynników produkcji w przemyśle i (zwłaszcza) w usługach niż w rolnictwie. W roku 2016 poza nielicznymi wyjątkami (Słowacja i Estonia) wartość WDB przypadająca na pracownika zatrudnionego w rolnictwie była znacznie niższa niż w przemyśle i usługach. Różnice są widoczne zarówno w państwach o bardzo wysokim zatrudnieniu w rolnictwie (Rumunia, Bułgaria, Grecja, Polska, Portugalia, Litwa, Słowenia), ale również w państwach o niewielkim udziale rolnictwa w strukturze zatrudnienia (Irlandia, Austria, Dania, Niemcy, Wielka Brytania, Luksemburg). Chociaż zjawisko wygląda podobnie, to ma różne przyczyny w każdej z tych grup. W państwach mniej zamożnych, niska wartość relacji WDB na jednego zatrudnionego $\mathrm{w}$ rolnictwie w stosunku do pozostałych sektorów wynika $\mathrm{z}$ dużej liczby zatrudnionych w rolnictwie (rys. 1 i niskiej wartości WDB generowanej przez ten sektor rys. 2). W państwach bogatszych natomiast, niska wartość relacji jest także skutkiem wysokiej WDB generowanej w przemyśle i usługach. 

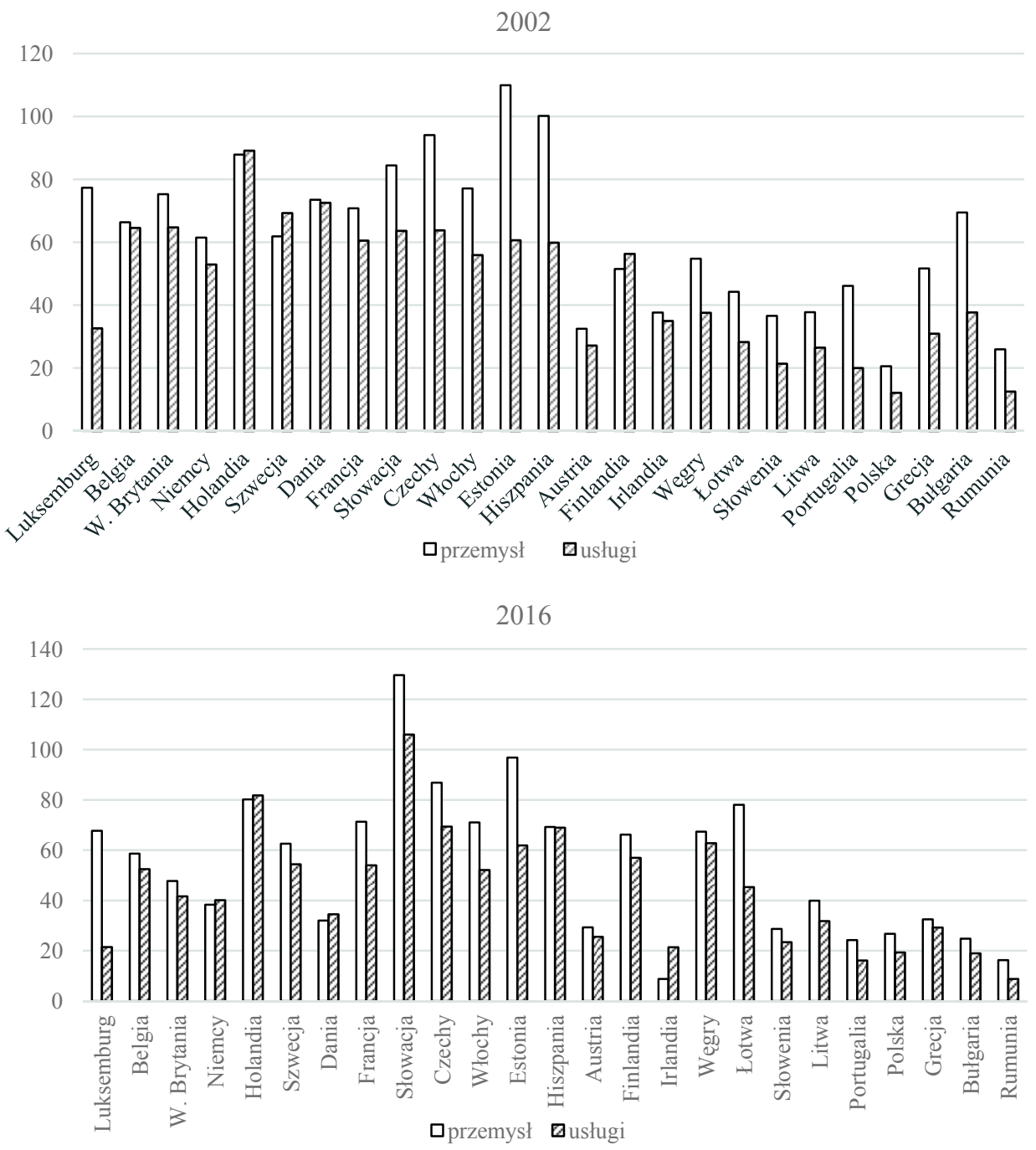

Rys. 3. WDB na 1 zatrudnionego $\mathrm{w}$ rolnictwie w relacji do WDB na 1 zatrudnionego w przemyśle i usługach $\mathrm{w}$ krajach UE w 2002 i 2016 roku (\%)

Fig. 3. GVA per 1 employee in agriculture in relation to GVA value per 1 employee in industry and in services in the EU countries in 2002 and $2016(\%)$

Źródło: opracowanie na podstawie danych EUROSTAT (2018).

Problem niskiej efektywności procesów wytwórczych w rolnictwie jest więc powszechny, a możliwości uzyskiwania dochodów przez osoby pracujące w tym sektorze zależą przede wszystkim od ich liczby, między którą będzie „dzielona” wytworzona WDB. Jak już zaznaczono wcześniej, nie ma w zasadzie możliwości znaczącego zwiększenia WDB w rolnictwie. Jednym z najważniejszych ograniczeń, uniemożliwiających wzrost 
wartości dodanej wytwarzanej przez rolnictwo w krajach UE jest dążenie do jego zrównoważenia w zakresie środowiskowym (wcześniej były to przede wszystkim limity produkcyjne). W odróżnieniu np. od rolnictwa amerykańskiego, rolnictwo europejskie nie ma charakteru przemysłowego, a stosowanie zwiększających wydajność środków chemicznych i organizmów modyfikowanych genetycznie jest ograniczone. Jak zauważa Czyżewski (2013), ze względu na wysokie koszty przyrodnicze i społeczne, charakterystyczna np. dla USA, przemysłowa ścieżka rozwoju rolnictwa nie może być uznana za właściwą. Poza tym, rolnictwo realizuje także funkcje pozaprodukcyjne, związane $\mathrm{z}$ nowymi funkcjami rolnictwa i rozwojem obszarów wiejskich, tworzące fundament rozwoju wielofunkcyjnego i zrównoważonego (Zegar, 2005; Wilkin, 2010; Kowalczyk, Sobiecki, 2011). Sama koncepcja zrównoważenia oraz wielofunkcyjności wsi i rolnictwa są fundamentem WPR (Kulawik, 2015). Pomimo niewątpliwej słuszności związania WPR z paradygmatem rozwoju zrównoważonego, ograniczenia narzucane rolnictwu europejskiemu w imię jego zrównoważenia wymuszają nieustanne dotowanie tego sektora. Jednak zarówno przemysłowa (pomimo wyższej wydajności), jak również europejska („przyjazna” środowisku i społeczeństwu) ścieżka rozwoju (model) rolnictwa nie umożliwia wypracowania WDB wystarczającej do zapewnienia rolnikom dochodów zbliżonych do osób pracujących $\mathrm{w}$ przemyśle i usługach, jeżeli poziom zatrudnienia $\mathrm{w}$ rolnictwie będzie zbyt wysoki.

Redukcja zatrudnienia w rolnictwie jest w wielu państwach procesem koniecznym, jednak niełatwym do przeprowadzenia. O ile w zakresie jakości produkowanej w gospodarstwach żywności i ochrony zasobów naturalnych można mówić o względnie dużej sile oddziaływania instrumentów WPR, to w przypadku optymalizacji zatrudnienia najważniejszymi czynnikami są: możliwość pozyskiwania przez ludność związaną z gospodarstwami pracy poza rolnictwem oraz przemiany demograficzne (Kołodziejczak i Wysocki, 2015). Są to czynniki w zasadzie egzogeniczne wobec rolnictwa. Jednak również sytuacja $\mathrm{w}$ rolnictwie ma wpływ na wielkość zatrudnienia $\mathrm{w}$ gospodarstwach rolnych, ponieważ procesy modernizacji i unowocześniania tego sektora wymuszają stopniowe zmniejszanie nakładów pracy. W sytuacji, kiedy pomimo występującego na skutek tych procesów niskiego zapotrzebowania technologicznego na siłę robocza, zatrudnienie w gospodarstwach rolnych pozostaje wysokie, pojawia się nadwyżka niewykorzystanej efektywnie siły roboczej nazywana inaczej bezrobociem ukrytym lub bezrobociem agrarnym (Kołodziejczak i Wysocki, 2015; W. Kołodziejczak, 2016b). Konsekwencją wysokiego zatrudnienia $\mathrm{w}$ rolnictwie, poza dużą skalą obciążenia gospodarstw rolnych kosztami osobowymi, są potencjalne problemy na rynku pracy $\mathrm{w}$ przypadku próby instytucjonalnego stymulowania procesów zmniejszania zatrudnienia $\mathrm{w}$ tym sektorze. Zjawisko to nie jest jednak jednorodne, a obok obszarów o nadmiernym zatrudnieniu w rolnictwie moga, w ramach tego samego kraju, istnieć obszary niedoboru siły roboczej, uzupełniane np. imigrantami zarobkowymi z zagranicy (por. Wysocki i Kołodziejczak, 2015; Górny i Kaczmarczyk, 2018). Równocześnie, ze względu na niedopasowania o charakterze strukturalnym, pomimo istnienia wolnych miejsc pracy $\mathrm{w}$ przemyśle i usługach, cześć ludności rolniczej nie może podjać zatrudnienia poza tym sektorem. Problem ten jest bardziej rozległy, niż tylko przywoływane często w literaturze przedmiotu niewystarczające, lub niedostosowane do potrzeb pracodawców, kwalifikacje. Przyczyny pozostawania ludności w nieefektywnym zatrudnieniu rolniczym mogą dotyczyć w zasadzie każdego niedostosowania jakościowego, ale także zbyt niskich stawek płac oferowanych poza rolnictwem na lokalnych rynkach pracy, związków rodzinnych i 
społecznych zniechęcających do migracji lub nieefektywności technologicznej procesów produkcji rolniczej w słabiej rozwiniętych gospodarstwach, jednak w tym przypadku zatrudnienie jest „nadmierne” jedynie w sensie ekonomicznym.

Redukcja zatrudnienia w rolnictwie powinna być pierwszym w kolejności sposobem na zmniejszenie dysparytetu dochodowego między ludnością rolniczą i utrzymującą się z pracy poza rolnictwem. Bez tego nie będzie możliwa optymalizacja wykorzystania pracy, ziemi i kapitału, trudniejsza będzie także minimalizacja negatywnego oddziaływania produkcji rolniczej na środowisko naturalne. Sytuację komplikuje dodatkowo zróżnicowanie przestrzenne poziomu zatrudnienia w rolnictwie, nawet wewnątrz poszczególnych krajów i regionów. Utrudnia to próby sformułowania racjonalnej i uniwersalnej polityki w tym zakresie i każe odwoływać się raczej do działań prowadzonych w skali całej gospodarki, niż tylko do polityki rolnej. Skuteczniejsze może być bowiem „przyciaganie" siły roboczej do sektorów pozarolniczych niż ewentualne próby jej „wypychania” z rolnictwa, np. za pomocą instrumentów polityki rolnej. Wcześniejsze badania wskazują, że proces zmniejszania zatrudnienia w rolnictwie jest uwarunkowany głównie rozmiarami popytu na pracę w sektorach pozarolniczych, strukturalnym dopasowaniem tego popytu do charakterystyki ludności wiejskiej, zwłaszcza związanej z rolnictwem oraz (długookresowo) zmianami demograficznymi (Kołodziejczak i Wysocki, 2015).

Przykład państw w których rolnictwo posiada niewielki udział w sektorowej strukturze zatrudnienia wskazuje jednak, że nie jest to warunek wystarczający do likwidacji dysparytetu dochodowego rolników. Najważniejszą barierą jest różnica w efektywności i w tempie wzrostu tej efektywności pomiędzy rolnictwem a przemysłem i usługami. Wynika to już z samej specyfiki rolnictwa i nie jest możliwe do wyeliminowania nawet $\mathrm{w}$ jego przemysłowym modelu, a tym bardziej w modelu europejskim, w którym cele ekonomiczne i produkcyjne nie są nadrzędnie traktowane wobec środowiskowych i społecznych. Dlatego, chociaż instrumenty transferowe nie powinny być traktowane priorytetowo przed racjonalizacją nakładów pracy, to nie można ich pominąć i przy pewnym, uzasadnionym technologicznie, ekonomicznie, przyrodniczo i społecznie poziomie zatrudnienia w rolnictwie muszą jeśli nie likwidować, to przynajmniej zmniejszać wielkość tego dysparytetu. Instrumenty te są konieczne nawet w sytuacji opisywanego na wstępie „przeszacowania” wynagrodzenia rolników. Kluczowym jest jednak ich kształt i sposób działania. Nie powinny one zastępować procesów przekształceń struktury zatrudnienia, a jedynie je uzupełniać tak, aby same nie stawały się siłą hamującą te przemiany.

\section{Podsumowanie i wnioski}

1. Najwyższy udział zatrudnienia $\mathrm{w}$ rolnictwie $\mathrm{w}$ ogólnej liczbie pracujących w gospodarce narodowej odnotowano w Rumunii, Bułgarii, a następnie w Grecji, Polsce i Portugalii. Najmniejszy udział zatrudnionych $\mathrm{w}$ rolnictwie występował $\mathrm{w}$ silnych gospodarczo państwach Europy Zachodniej: w Luksemburgu, Belgii, Wielkiej Brytanii, Niemczech i Szwecji. Wśród państw o niskim udziale rolnictwa w strukturze zatrudnienia znajdują się jednak także przedstawiciele części środkowej i wschodniej Europy: Słowacja, Czechy i Estonia.

2. Państwa postsocjalistyczne o wysokim udziale rolnictwa w sektorowej strukturze 
zatrudnienia posiadają porównywalny między nimi udział zatrudnienia w przemyśle (wyższy niż państwa zachodnie), natomiast „nadwyżka” zatrudnienia w rolnictwie występująca w stosunku do średniej UE odpowiada w nich, w przybliżeniu, „niedoborowi” zatrudnienia $\mathrm{w}$ usługach. Zatem można spodziewać się, że procesy zmian struktury zatrudnienia będą przebiegały z „pominięciem” klasycznego wzorca teorii trzech sektorów, a uwalniania z rolnictwa ludność będzie absorbowana przez sektor usług.

3. Proces zmian sektorowej struktury zatrudnienia będzie prawdopodobnie warunkowany przez tempo wzrostu zapotrzebowania na usługi, dostosowanie strukturalne dotyczące dopasowania cech ludności rolniczej do zapotrzebowania na siłę roboczą w sektorze usług oraz tempo przekształceń strukturalnych na wsi, zwłaszcza modernizację procesów produkcji i konsolidację własności oraz użytkowania ziemi rolniczej.

4. Relacje pomiędzy udziałem przemysłu w sektorowej strukturze zatrudnienia a wielkością wytwarzanej przez przemysł WDB są zbliżone w poszczególnych krajach. Równocześnie, „brakująca” w strukturze część WDB w krajach o wysokim poziomie zatrudnienia w rolnictwie uzupełniania jest przez sektor usług. Państwa te charakteryzują się zwykle niższą WDB w skali całej gospodarki, można więc przypuszczać, że WDB niewytworzona przez „nadmiarowe” zatrudnienie w rolnictwie po prostu przepada. $Z$ tego punktu widzenia, wielkość zatrudnienia w rolnictwie odpowiadająca utraconej WDB określa w przybliżeniu poziom nieefektywnej nadwyżki zatrudnienia w sektorze rolniczym, inaczej nazywanej bezrobociem ukrytym.

5. Poza nielicznymi wyjątkami (Słowacja i Estonia) wartość WDB przypadająca na pracownika zatrudnionego w rolnictwie była w 2016 roku znacznie niższa niż w przemyśle i usługach. Różnice są widoczne w państwach o bardzo wysokim zatrudnieniu w rolnictwie (Rumunia, Bułgaria, Grecja, Polska, Portugalia, Litwa, Słowenia) ale również w państwach o niewielkim udziale rolnictwa w strukturze zatrudnienia (Irlandia, Austria, Dania, Niemcy, Wielka Brytania, Luksemburg). Chociaż zjawisko wygląda podobnie, to ma różne przyczyny w każdej z tych grup. W państwach mniej zamożnych, niska wartość relacji WDB per capita $\mathrm{w}$ rolnictwie $\mathrm{w}$ stosunku do pozostałych sektorów wynika $\mathrm{w}$ znacznej części ze zbyt dużej liczby zatrudnionych $\mathrm{w}$ rolnictwie. W państwach bogatszych, charakteryzujących się relatywnie niskim poziomem zatrudnienia $\mathrm{w}$ rolnictwie, niska wartość relacji jest skutkiem przede wszystkim wysokiej WDB wytwarzanej w przemyśle i usługach.

6. Przyjmując zasadę, że wynagrodzenie czynników produkcji powinno wynikać przede wszystkim $\mathrm{z}$ ich produktywności oraz przyjmując, że $\mathrm{w}$ dającej się przewidzieć perspektywie czasowej nie ma znaczących możliwości zwiększenia wartości dodanej generowanej przez rolnictwo należy stwierdzić, że minimalizacja dysparytetu dochodowego rolników jest możliwa poprzez dalszą ewolucję sektorowej struktury zatrudnienia $\mathrm{w}$ kierunku minimalizacji udziału $\mathrm{w}$ tej strukturze rolnictwa i zwiększania udziału sektorów pozarolniczych, zwłaszcza usług.

7. Racjonalizacja poziomu zatrudnienia $\mathrm{w}$ rolnictwie jest także drogą do poprawy poziomu jego zrównoważania ekonomicznego i społecznego. Dopiero w dalszej kolejności powinny być uwzględniane instrumenty oparte na transferach finansowych $\mathrm{z}$ sektorów pozarolniczych do rolnictwa, ponieważ obciażają one bardziej efektywne sektory i długookresowo mogą spowalniać naturalną ewolucję poziomu zatrudniania w rolnictwie. Jednak ze względu na niemożliwe do zniwelowania różnice efektywności występujące pomiędzy rolnictwem i sektorami pozarolniczymi, przy pewnym, uzasadnionym technologicznie, ekonomicznie, przyrodniczo i społecznie poziomie zatrudnienia $\mathrm{w}$ 
rolnictwie, transfery nadwyżki wytworzonej w przemyśle i usługach muszą jeśli nie likwidować, to przynajmniej zmniejszać wielkość tego dysparytetu.

\section{Literatura}

Czyżewski, A. (1989). Systemowe uwarunkowania przełomu jakościowego w polityce rolnej (The system conditions of a qualitative change in agricultural policy). Ruch Prawniczy, Ekonomiczny i Socjologiczny, 51(4), 155-169.

Czyżewski, A. (2013). O nowy paradygmat rozwoju rolnictwa: refleksje nad książką J.S. Zegara „Współczesne wyzwania rolnictwa" (A New Paradigm of Agricultural Development: reflections on the book "Contemporary Challenges of Agriculture" by J.S. Zegar). Ekonomista, 6, 831-841.

Czyżewski, B. (2012). Produktywność zasobów w rolnictwie w Polsce wobec paradygmatu zrównoważonego rozwoju (Resource Productivity in Polish Agriculture: Towards the Paradigm of Sustainable Development). Studia Ekonomiczne, 2(73), 165-188.

Doward, A. (2013). Agricultural labour productivity, food prices and sustainable development impacts and indicators. Food Policy, 39, 40-50.

Fisher, A.G.B. (1933). Capital and the Growth of Knowledge. The Economic Journal, 43(171), 379-389.

Fisher, A.G.B. (1939). Production, primary, secondary and tertiary. Economic Record, 15(1), 24-38.

Fisher, A.G.B. (1945). Economic Progress and Social Security. MacMillan \& Company Limited, London.

Flejterski, S., Klóska, R., Majchrzak, M. (2012). Usługi w teorii ekonomii (Services in the theory of economics). W: S. Flejterski, A. Panasiuk, J. Perenc, G. Rosa (red.) Współczesna ekonomika usług (Contemporary economics of services). Wyd. Nauk. PWN, Warszawa.

Góral, J., Rembisz, W. (2018). Remunerations and labour productivity in agriculture against a background of other economy sectors. Acta Sci. Pol. Oeconomia, 17(1), 49-58.

Górny, A., Kaczmarczyk, P. (2018). A known but uncertain path: The role of foreign labour in Polish agriculture. Journal of Rural Studies, 64, 177-188.

Kiełczewski, D. (2016). Racjonalność człowieka gospodarującego w ujęciu koncepcji homo sustinens (Rationality of managing man in the concept of homo sustinens). Prace Naukowe Uniwersytetu Ekonomicznego we Wroctawiu, 449, 269-276.

Kołodziejczak, M. (2016). Ocena korzystania z usług w gospodarstwach rolnych krajów Unii Europejskiej analiza typologiczna (Assessment of the Use of Services on Farms in the European Union Countries - a Typological Analysis). Problemy Rolnictwa Światowego, 16(3), 192-198.

Kołodziejczak, M. (2018). Assessment of the use of services in agriculture of the EU countries based on inputoutput tables. Proceedings of the 2018 International Conference "Economic Science for Rural Development" No 47, Jelgava, LLU ESAF, 9-11 May 2018, 149-155.

Kołodziejczak W. (2016a). Nadwyżka zatrudnienia w polskim rolnictwie - projekcja na tle państw Unii Europejskiej (The Surplus of Employment in Polish Agriculture - A Simulation Against the European Union Countries), Problemy Rolnictwa Światowego, 16(3), 121-149.

Kołodziejczak, W. (2016b). Hidden unemployment in Polish agriculture in 1995-2015. Journal of Agribusiness and Rural Development, 4(42), 545-556.

Kołodziejczak, W., Wysocki, F. (2013). Bezrobocie ukryte w polskim rolnictwie w 2010 roku - próba symulacji skali zjawiska (Hidden Unemployment in Polish Agriculture in 2010 - Simulation of the Problem Scale). Roczniki Naukowe SERiA, 15(2), 158-164.

Kołodziejczak, W., Wysocki, F. (2015). Determinanty aktywności ekonomicznej ludności wiejskiej w Polsce (Determinants of the economic activity of rural population in Poland), Uniwersytet Przyrodniczy w Poznaniu.

Kowalczyk, S., Sobiecki, R. (2011). Europejski model rolnictwa wobec wyzwań globalnych (The European model of agriculture in relation to global challenges). Zagadnienia Ekonomiki Rolnej, 4(329), 35-58.

Kraciuk, J. (2015). Paradygmat homo oeconomicus w aspekcie rozwoju ekonomii heterodoksyjnej (Homo Economicus Paradigm in Terms of Development of Heterodox Economics). Prace Naukowe Uniwersytetu Ekonomicznego we Wroctawiu, 401, 211-219.

Kulawik, J. (2015). Globalne i europejskie determinanty WPR (Global and European determinants of the CAP). Zagadnienia Ekonomiki Rolnej, 4(345), 38-58.

Kwiatkowski, E. (1980). Teoria trzech sektorów gospodarki. Prezentacja i próba oceny (Theory of three sectors of the economy. Presentation and an attempt to evaluate). Państwowe Wydawnictwo Naukowe, Warszawa.

Matuszczak, A. (2013). Zróżnicowanie rozwoju rolnictwa w regionach Unii Europejskiej w aspekcie jego 
zrównoważenia (Diversification of agricultural development in regions of the European Union in the aspect of its sustainability). Wyd. Nauk. PN, Warszawa.

Rembisz, W. (2016). Relacje wynagrodzenia i wydajności czynnika pracy w rolnictwie na tle gospodarki narodowej i jej sektorów w Polsce w okresie 2005-2012 (Relationship between Labour Productivity and Its Remuneration in Agriculture in Comparison with National Economy and Its Sectors in Poland in the Period 2005-2012). Wieś i Rolnictwo, 2(171), 41-58.

Wąsowicz, J. (2013). Sektorowe zróżnicowanie wydajności pracy w polskiej gospodarce (Sectoral Disparities of Labour Productivity in the Polish Economy). Studia Ekonomiczne, 160, 190-198.

Wilkin, J. (2010). Wielofunkcyjność rolnictwa. Dobra dostarczane przez rolnictwo w świetle teorii dóbr publicznych (The multiple outputs of agriculture from the perspective of public goods theory). W: J. Wilkin (red.) Wielofunkcyjność rolnictwa. Kierunki badań, podstawy metodologiczne i implikacje praktyczne (Multifunctional agriculture. Research trends, methodological basis and practical implications). IRWiR PAN, Warszawa, 41-52.

Zawalińska, K, Majewski, E., Wąs, A. (2015). Długookresowe zmiany w dochodach z polskiego rolnictwa na tle krajów Unii Europejskiej (Long-term changes in the incomes of the Polish agriculture compared to the European Union countries). Roczniki Naukowe SERiA, 17(6), 364-354

Zegar, J. St. (red.) (2005). Koncepcja badań nad rolnictwem społecznie zrównoważonym (The concept of research on socially sustainable agriculture). Program Wieloletni 2005-2009, 11, IERiGŻ-PIB Warszawa.

\section{Do cytowania / For citation:}

Kołodziejczak W. (2018). Zatrudnienie i wartość dodana brutto w sektorach gospodarki państw Unii Europejskiej w latach 2002 i 2016. Problemy Rolnictwa Światowego, 18(4), 270-283; DOI: $10.22630 /$ PRS.2018.18.4.117

Kołodziejczak W. (2018). Employment and Gross Value Added in the Sectors of the European Union Economy in 2002 and 2016 (in Polish). Problems of World Agriculture, 18(4), 270-283; DOI: $10.22630 /$ PRS.2018.18.4.117 